\title{
MILK AND VITA CHESSE PACKAGING LOSSES IN A DAIRY PLANT
}

\author{
Hanafy W.M. *
}

ABSTRACT

This research was conducted to identify the damaged packages milk and cheese losses at different rates of packging processes. Six rates were studied for two different products of fluid milk and vita cheese using tetra brick aseptic packaging machine in addition to quantity of losses milk. Experiments were carried out in Green Land middle east Co. plant for food production at $10^{\text {th }}$ of Ramadan City with in the period from Jan., 2015 to Feb., 2015.

The percent of damage packages for milk or cheese and losses quantity of milk in the plant were evaluated.

*The percent of damaged milk packages in different tetra brick aseptic packaging machine rate for packages volumes (milk $200 \mathrm{ml}$, milk mix fruit $200 \mathrm{ml}$, milk $500 \mathrm{ml}$, milk $1000 \mathrm{ml}$ and milk mix $1000 \mathrm{ml}$ ) ranged from $(0.60 \sim 1.30) \%,(0.70 \sim 1.70) \%,(0.60 \sim 1.20) \%,(0.41 \sim 1.60) \%$ and $(0.70 \sim 3.10) \%$ while the percent of losses of milk quantity were ranges $(1 \sim 4.22) \%, \quad(1.22 \sim 2.26) \%, \quad(1.25 \sim 3.22) \%, \quad(0.92 \sim 2.98) \%$ and (1.17 3.63) \% in plant respectively.

*The percent of damaged vita cheese packages in different tetra brick aseptic packaging machine rate for packages volumes (vita cheese 250 gm and vita cheese $500 \mathrm{gm})$ were ranges (0.23 1.72) \% and (0.10 0.58) $\%$ in plant respectively.

The results and obtained data cleared that the suitable machine rate using six different packaging speed for each volum \& product were respectiviely.

*Milk 200 ml, mix milk $200 \mathrm{ml}$, milk $500 \mathrm{ml}$ milk $1000 \mathrm{ml}$ and mix milk $1000 \mathrm{ml}$ were $(7140,6540,5160,6420 \& 5760) \mathrm{pack} / \mathrm{h}$ in the plant respectively.

*Vita cheese (250 and 500) gm were (5160\& 5040) pack/h in plant respectively.

Key words: Packaging, milk, vita chesse, plant, losses, saving, Tetra brick aspetic packiging machine.

*Lecturer, of Ag. Eng. Dept., Fac. of Agric.and Natural Resources, Aswuan Univ. 


\section{INTRODUCTION}

ccounting and comparing volumes of damaged packages and
quantity of product losses in packging processes for two
different product including milk and vita cheese by six different rate packaging system in addation to quantity of losses milk in food processing plant such as milk, mixmilk and vita chesse can be applied to compute damaged packages (bad welding or not complete filled) and losses product in the plant during packaging process and change packaging machine rate .On this study sex rates for packaging evaluated and comparing with the others the to determine the ratio of packages damaged and product losses in this speed to arrived to the best rate which reduce the packages damaged and product losses .

Egyptian E.A.A.I.M. (2015) founed that the sterilized milk packaged in Tetra Brick Aseptic portion packages validity period 6 months Compared to pasteurized milk filled in bottles of polyethylene validity period was a week only. The estimated losses ratio were $2 \%$ for aseptic packaging machines which used in packaging sterilized milk.

Dairy-technology (2014) mentioned that packaging operation, losses are mostly due to over filling, spillage and failure of packaging. In milk packaging, the loss of 0.5 to $1.0 \%$ is general. The general reason for losses during packaing is negligence, carelessness and machine sensitivity.

Wikipedia (2014) reported that Aseptic food preservation methods allow processed food to keep for long periods of time without preservatives, as long as they are not opened. The aseptic packages are typically a mix of paper (70\%), polyethylene (LDPE) (24\%), and aluminum (6\%), with a tight polyethylene inside layer.

Alberto and Giulia, (2013) : said that the protection of the product is one of the basic functions of packaging for both companies and users. An unprotected product could cause product waste, which is negative from both the environmental and the economic point of view. Packages must protect products during manufacturing and assembly (within the factory), 
storage and picking (within the warehouse) and transport (within the vehicle) from surrounding conditions, against losses.

Kishor (2007) said that ultra-high temperature processing ( UHT) is the partial sterilization of food by heating for a short time, around 1-2 seconds, at a temperature exceeding $135^{\circ} \mathrm{C}$ and then kept inside the aseptic package. Aseptic packaging machines are very expensive and UHT milk depends entirely on it.

Chauhan et al. (2006) said that The double-toned milk has revealed a loss of Rs 0.16 per litre. Therefore, the study has suggested that the doubletoned milk production should be raised at least to the break-even level to avoid losses in this product, if there is a market demand for it, or the resources of this product could be shifted to some other profitable products.

Hassanain et al. (2005) identified the most effective factors which affecting the economies of white cheese in Egypt. The major findings indicate that the production under the full capacity of processing units, the results of the study relived that the most important items affecting on production costs are kind of milk and the processing technique. The study calculated also the cost of production process, packaging operation and packaging losses for milk, fresh cheese, stored cheese, dry cheese, vita cheese and domitatte cheese. The result of the study revealed that the important items affecting the production costs are, as well as kind of milk and the processing technique. The comarative analysis of the losses in packaging and processing vita chesse in the processing units was highest value in Dakahlia governorate compaed to the great Cairo was lowest and efficient.

Sri-hari-rao (1990) discussed losses in dairy industry that have financial implications in terms of milk, energy packaging materials and dairy products. He added that the sources of losses include spoilage, wasteage of surplus material, milk remaining in plant due to inadequate drainage of equipment, processing losses, losses due to analytical variations, packaging losses and storage losses.

Choudhary (1989) discussed a research needs of Indian dairy industry in milk production, processing and packaging, he added that the different 
aspects covered include milk handling losses, price structure, dairy equipment for small-scale milk processing and packaging.

The objectiv of this study are to:

1- Accounting and comparing volumes of damaged packages and quantity of product losses in packaging process.

2-Suggested the best speed or rate for tetra brick aseptic packaging machine which reduce the packages damaged and product losses by evaluated and comparing each speed with the others to determine the ratio of packages damaged and product losses of this speed.

\section{MATERIALS AND METHODS}

The experiments were carried out in "Green Land" Middle East Co. for food production at $10^{\text {th }}$ of Ramadan City. In This research six speed for packaging were evaluated and comparing with others the to determine the ratio of damaged packages and milk losses in this speed to be arrived to the best rate which reduce the damaged packages and milk losses. This research was conducted to quantify the tetra pack damaged packages in different machine rate and quantify also quantity losses milk for (Tetra Pak) TP milk 1000 ml, TP milk mix fruit 1000 ml, TP milk 500 ml, TP milk $200 \mathrm{ml}$ and TP milk mix fruit $200 \mathrm{ml}$ in addation to the tetra pack damaged packages in different machine rate for TP vita cheese $250 \mathrm{gm}$ and TP vita cheese $500 \mathrm{gm}$.

\section{Tetra brick aseptic packaging machine (Type: TBA/19-010V):-}

The machine packages liquid food in tetera brick aseptic prortion packages with filler capacity ranged from 7500 to $6000(-0 \%+4 \%)$ per hour and volumes available all exisiting TBA/19 volumes and this machine export from Switzerland.It is an automatic splicing unit with double reel for packaging material, it consists of (US-version) provied with a six-channel recorder to monitor different machine parameters, offset splicing table, multi-installation platforms and separate cleaning unit. In this study the experiments were carried out on milk packages volumes $200 \mathrm{ml}, 250 \mathrm{ml}, 500 \mathrm{ml}$ and 1 litter.The pasteurized milk pasteurized by hight-temperature-short-time (HTST) system, using hot water at temperature of $87^{\circ} \mathrm{C}$ with holding time 30 second then sterilized by ultera-hight-temperature (UHT) system under pressure by hot water at 

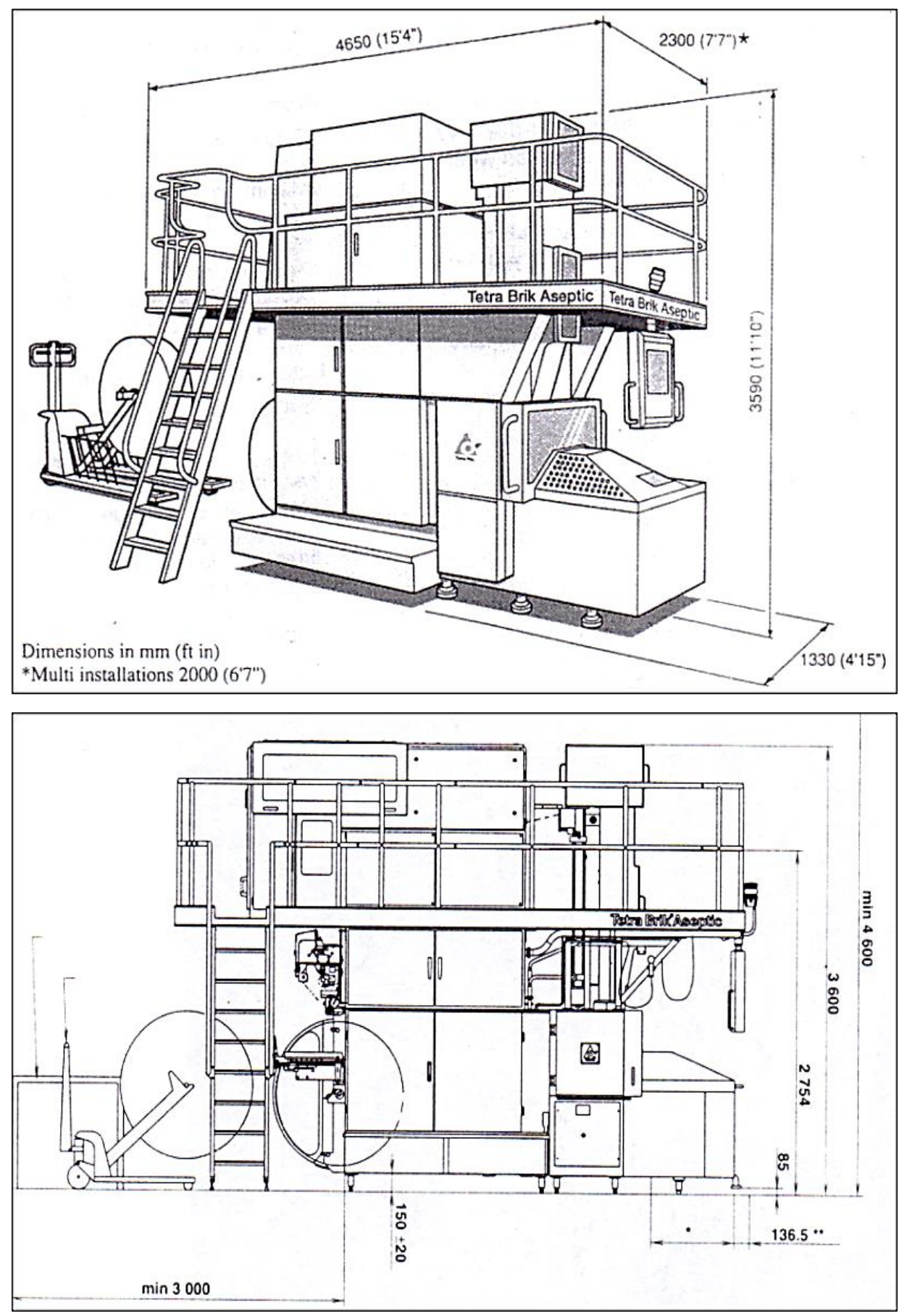


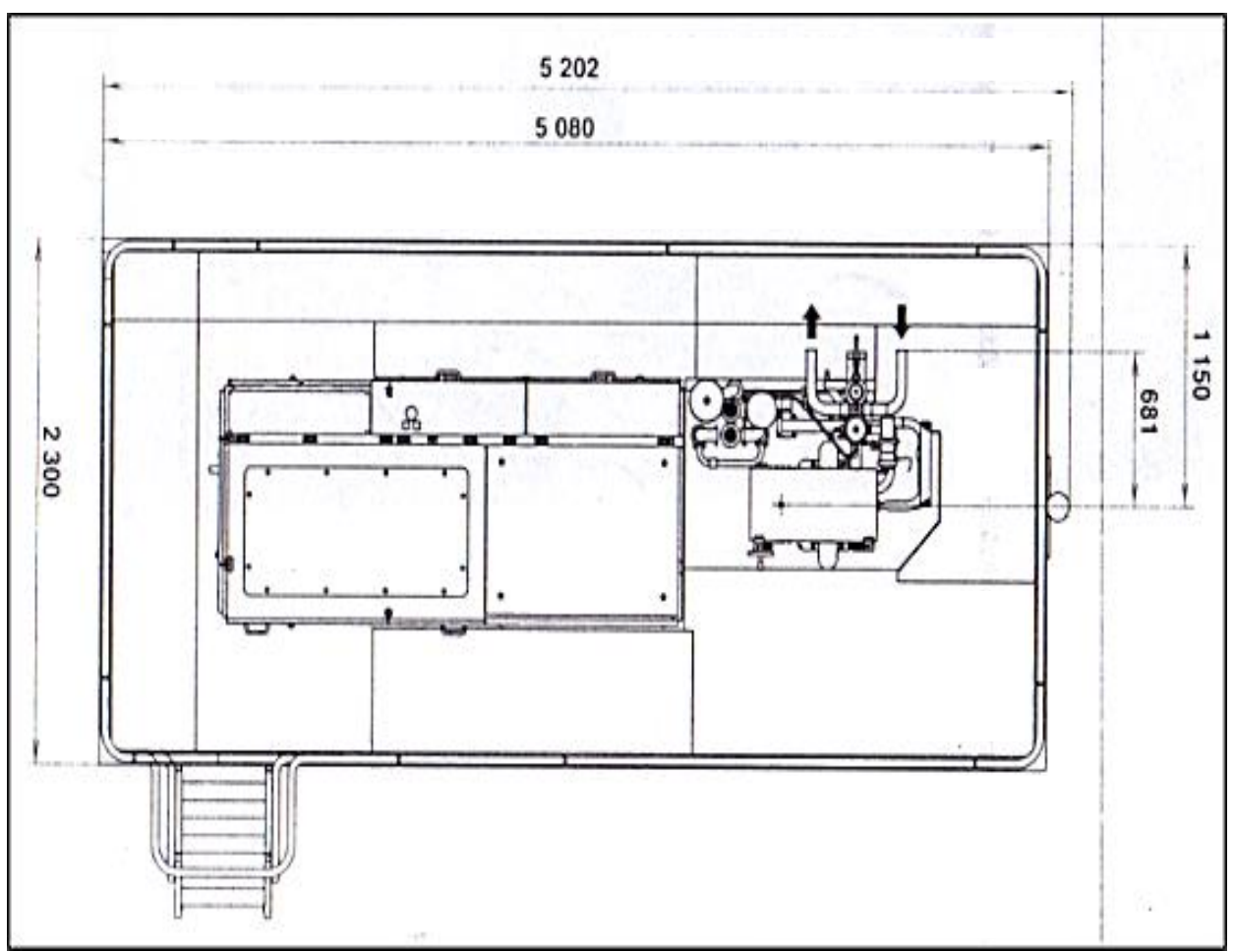

Fig. (1): Tetra brick aseptic packaging machine ( Type: TBA / 19 $010 \mathrm{~V})$ in plant.

temperature of $137{ }^{\circ} \mathrm{C}$ with holding time 4 seconds, after that, the product is cooled to $25^{\circ} \mathrm{C}$ and pumped to packaging storage tank.

\section{Milk packaging depart:}

Sterilized milk lead to tetra brick aseptic packaging machine to be packaged in tetra brick aseptic portion packages in package volumes of (200 $\mathrm{ml}-500 \mathrm{ml}-1000 \mathrm{ml}$ ) then the packages is transport by conveyor to the tetra capping machine which provide the packages with plastic caps or tubex straw applicator which provide the packages with tubex then the packages is transport by conveyor to tetra card board packer which collect packages in small groups in warp around box, then the boxes transported by conveyor to shrink machine to be wrapped the boxes with plastic cover. Finally the product led to storage. 


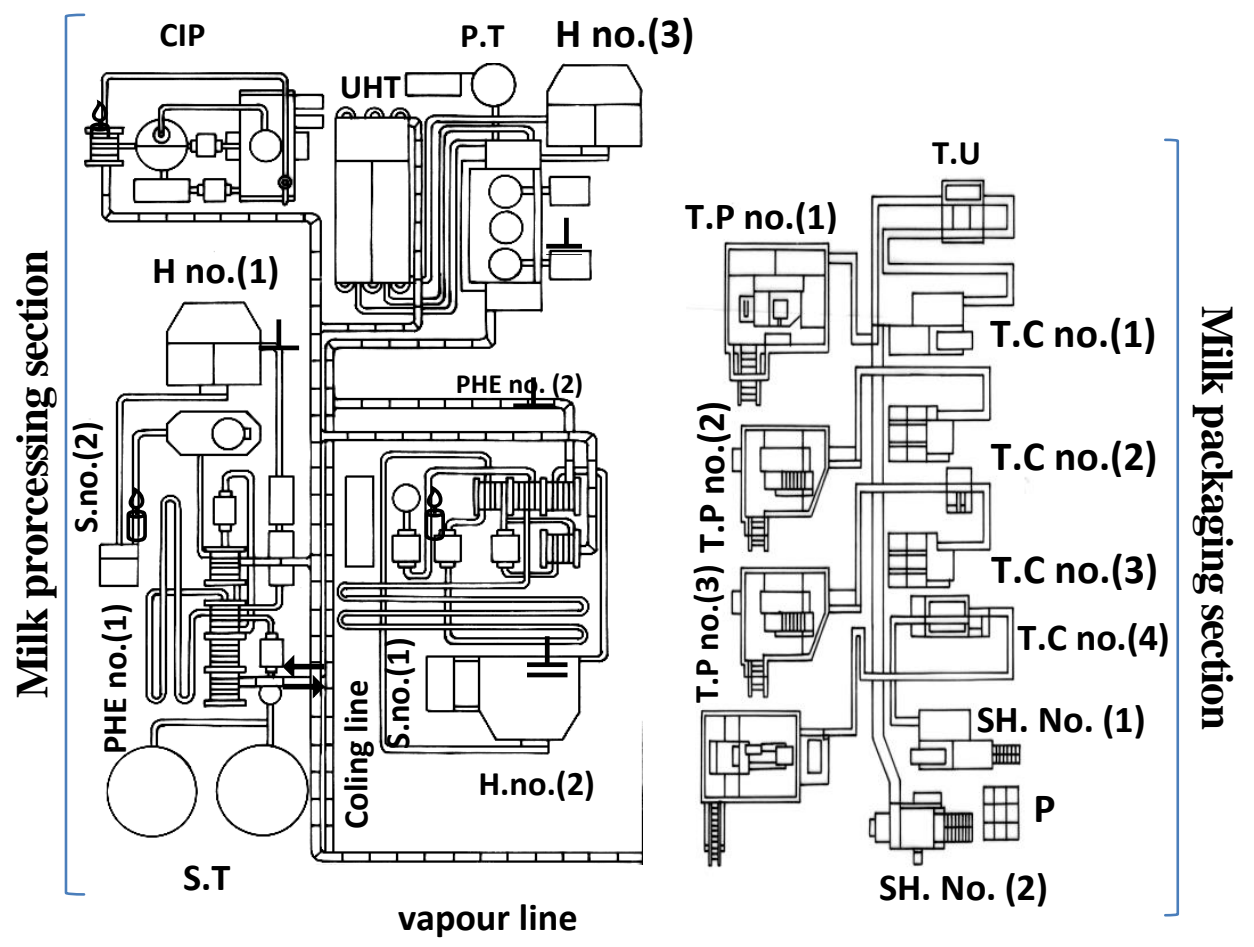

Fig. (2): Milk production lines and packaging lines in plant.

\begin{tabular}{cl} 
Symbol & \multicolumn{1}{c}{ Part Name } \\
PHE & Plat heat exchanger device no.(1and 2) \\
UHT & Ultra heigh temperature device \\
H & Homogenizer no.(1,2and 3) \\
S & Separator no.(1 and 2) \\
S.T & Storage tanks \\
P.T & Packaging tanks \\
T.P & Tetra brick aseptic packaging no.(1,2,3 and 4)
\end{tabular}

$$
\begin{array}{cl}
\text { Symbol } & \multicolumn{1}{c}{\text { Part Name }} \\
\text { T.C } & \text { Tetra cardboard packer } \\
& \text { no.(1, 2,3 and 4) } \\
\text { TU } & \text { Tubex straw applicator } \\
\text { SH. } & \text { Shrink no.(1 and } 2) \\
\text { P } & \text { Product } \\
\text { CIP } & \text { Cleaning in place } \\
& \text { device no.(1) }
\end{array}
$$

\section{Packaging milk losses:}

The research was conducted to quantify the tetra pack damaged packages for TP milk $1000 \mathrm{ml}$, TP milk mix fruit $1000 \mathrm{ml}$, TP milk $500 \mathrm{ml}$, TP milk $200 \mathrm{ml}$ and TP milk mix fruit $200 \mathrm{ml}$ in different machine rate. The research quantify also losses of milk at the same machine rate.

The pasteurized milk led to ultra filtration (UF) device and reverse osmosis membrane Ro device which filterated the curd then the curd 
pasteurized by (HTST) system, using hot water at temperature of $85{ }^{\circ} \mathrm{C}$ with holding time 30 second then the retentate is pumped to mixing vats where we add salt, starter and mixed together by about 25 minutes then soft cheese is led to packaging depart cheese at a temperature $36{ }^{\circ} \mathrm{C}$.

\section{Cheese packaging depart:}

Soft cheese is pumped to tetra brick aseptic packaging machine to be packaged in tetra brick aseptic portion packages in package weight $(250 \mathrm{gm}-500 \mathrm{gm})$ then the packages is transported by conveyor to tetra card board packer which collect packages in small groups in wrap around box, then the box transported by conveyor to shrink machine to be wrappe the boxes with plastic cover. Finally the product led to storage.

\section{Packaging cheese losses:}

This research was conducted to quantify the tetra pack packages damaged for TP vita cheese $250 \mathrm{gm}$ and TP vita cheese $500 \mathrm{gm}$ in different machine rate.

\section{The available data was divided in two groups:}

\section{1- Scheduled data}

\section{2- Measured data}

Scheduled of daily shafts product volume; worker time, product quantity losses

Measured of tetra brick aseptic Packaging machine rat on sex speed for packaging and comparing to determine the ratio of packages damaged from milk and cheese and its losses in this speed to be arrived to the best speed which reduce the damaged packages and product losses. These informations were analyzed .

\section{Data collection points:}

(1) Mass flow rate (by rate counter in the panel unit).

(2) Outlet and inlet temperatures of thermed product (by digital temperature thermometer in a panel unit).

(3) Packages losses and machine rate (by packages rate counter in the panel unit). 


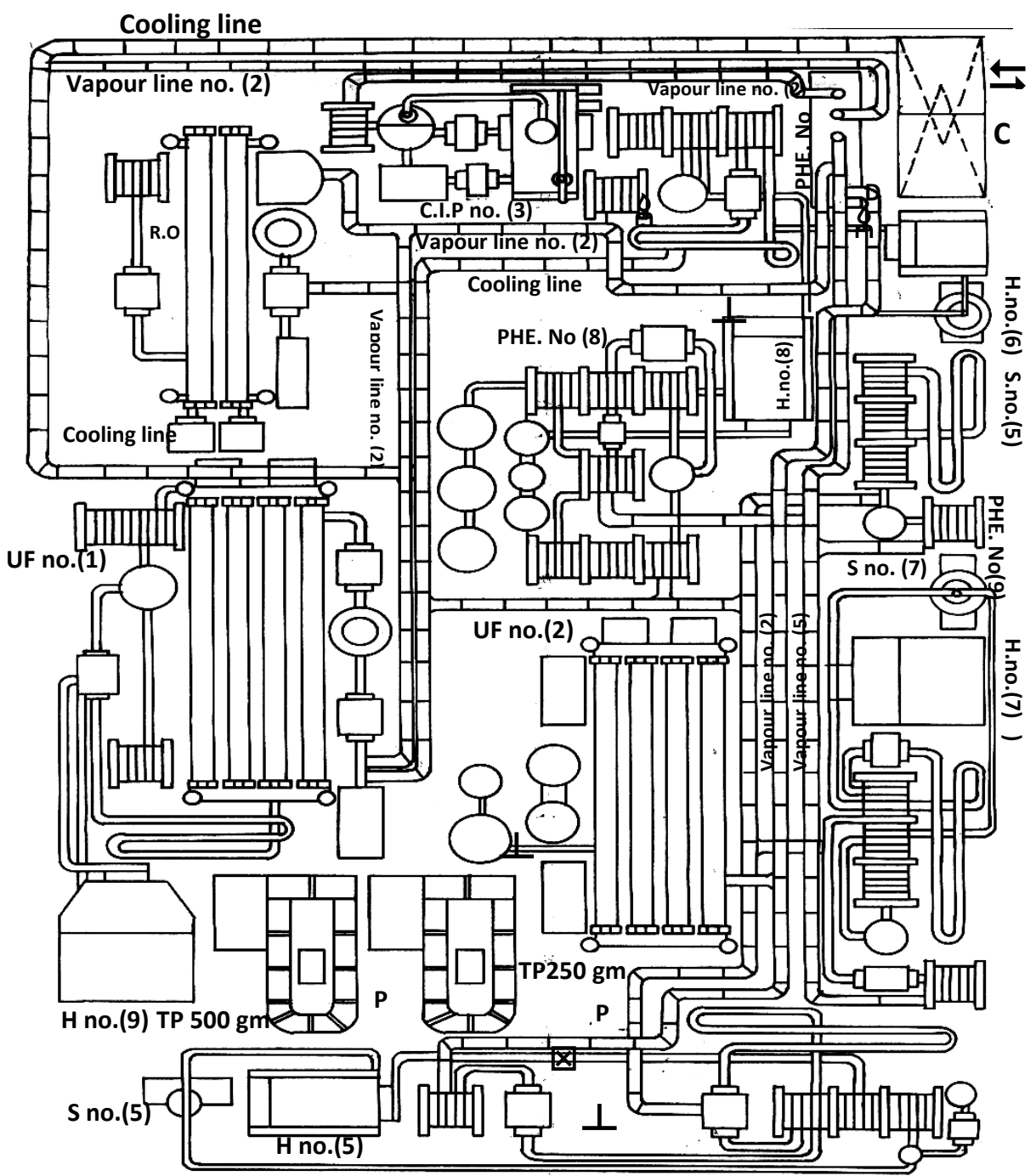

Fig. (3): Milk production lines and packaging lines in plant.

Symbol

Part Name

Symbol

Part Name

PHE Plat heat exchanger device no ( 5, T.P Tetra brick aseptic pack.(250 $6,7,8$ and 9 )

$\mathrm{H} \quad$ Homogenizer no.(5, 6, 7, 8 and 9$)$

D Distribution battery no. (2)

S Separator no. (5, 6 and 7$)$

C Cooling unite no (2)

U.F Ultra filtration device no.( (1and 2)

CIP Cleaning in place device no. (3)

R.O Curd filtration device

P Product 


\section{Losses Calculation}

1- The percent of damaged or losses packages

$$
\% \mathrm{TP}_{\mathrm{L}}=\frac{\mathrm{TP}_{\mathrm{R}}-\mathrm{TP}_{\mathrm{P}}}{\mathrm{TP}_{\mathrm{R}}} \times 100 \longrightarrow
$$

where

$$
\begin{aligned}
& \mathrm{TP}_{\mathrm{R}}=\text { Number of packaging machine rate(pack./h) } \\
& \mathrm{TP}_{\mathrm{P}}=\text { Number of packaging machine product (pack./h) }
\end{aligned}
$$

2- The percent of quantity milk losses

$$
\% q_{M L}=\frac{q_{M}-q_{M P}}{q_{M}} \times 100 \longrightarrow(2)
$$

where

$$
\begin{gathered}
q_{M}=\text { quantity of milk processed to package at the same } \\
\text { Machine rate (lit/h) } \\
q_{M P}=\text { quantity of milk packaged at the same } \\
\text { Machine rate }(\text { lit } / \mathrm{h})
\end{gathered}
$$

\section{RESULTS AND DISSCUATIO}

Damaged packages and losses by tetra brick aseptic packaging machine for packaging UHT milk and chesse in plant using six speeds for packaging evaluated and comparing with the others as follows :-

\section{1- Tetra brick aseptic packaging milk $200 \mathrm{ml}$ in plant :}

Comparing between the different rate for milk $200 \mathrm{ml}$ produce by tetra brick aseptic packaging machine and damaged packages in addition to losses of milk using six speeds were 6180, 6540, 6720, 6960, 7140 and 7320 packages/h with a percentage of damaged packages $1.30 \%, 0.60 \%$, $0.91 \%, 1 \%, 0.70 \%$, and $0.90 \%$ while the losses of milk with a percentage of $3.90 \%, 1.36 \%, 2.96 \%, 1 \%, 3.38 \%$, and $4.22 \%$ respectively are presented in Tabel (1) and Fig.(4). The data can be indicated that the highest value of damaged packages was accompanied with a speed 6180 packages/h, while the lowest one with a speed 6540 packages $/ \mathrm{h}$. 


\section{2- Tetra brick aseptic packaging milk mix fruit $200 \mathrm{ml}$ in plant:}

Comparing between the different rate for milk mix fruit $200 \mathrm{ml}$ produce by tetra brick aseptic packaging machine and damaged packages in addition to losses of milk using six speeds were 6240, 6540, 6660, 6900, 7020 and 7320 packages/h with a percentage of damaged packages were $1.30 \%, 0.70 \%, 0.90 \%, 1.70 \%, 0.80 \%$, and $1 \%$ while the losses of mix milk with a percentage of $2.10 \%, 1.86 \%, 1.94 \%, 1.61 \%, 2.26 \%$, and $1.22 \%$ respectively are presented in Tabel (2) and Fig.(5). The data can be indicated that the highest value of damaged packages was accompanied with a speed 6900 packages/h, while the lowest one with a speed 6540 packages/h.

\section{3- Tetra brick aseptic packaging milk $500 \mathrm{ml}$ in plant :}

Comparing between the different rate for milk $500 \mathrm{ml}$ produce by tetra brick aseptic packaging machine and damaged packages in addition to losses of milk using six speeds were 4020, 4200, 4500, 4860, 5100 and 5160 packages/h with a percentage of damaged packages were $0.82 \%$, $0.91 \%, 1 \%, 1.20 \%, 1.10 \%$, and $0.60 \%$ while the losses of milk with a percentage of $3.06 \%, 2.30 \%, 3.22 \%, 1.25 \%, 1.55 \%$, and $2.36 \%$ respectively are presented in Tabel (3) and Fig.(6). The data can be indicated that the highest value of damaged packages was accompanied with a speed 4860 packages/h, while the lowest one with a speed 5160 packages/h.

\section{4- Tetra brick aseptic packaging milk $1000 \mathrm{ml}$ in plant :}

Comparing between the different rate for milk $1000 \mathrm{ml}$ produce by tetra brick aseptic packaging machine and damaged packages in addition to quantity of losses milk using six speeds were 5580, 5640, 5760, 6300, 6420 and 6900 packages/h with a percentage of damaged packages were $1.20 \%, 0.60 \%, 1.60 \%, 1.30 \%, 0.41 \%$, and $0.90 \%$ while the losses of milk with a percentage of $1.13 \%, 0.92 \%, 1.08 \%, 1.47 \%, 1.87 \%$, and $2.98 \%$ respectively presented in Tabel (7) and Fig.(4). The data can be indicated that the highest value of damaged

packages was accompanied with a speed 5760 packages/h, while the lowest one with a speed 6420 packages/h. 
Table (1):Comparing between different rats for milk $200 \mathrm{ml}$ produce by tetra pack machine and damaged packages in plant.

\begin{tabular}{|c|c|c|c|c|c|c|}
\hline \multirow{2}{*}{$\begin{array}{l}\text { Percent } \\
\text { of losses } \\
\text { milk \% }\end{array}$} & \multicolumn{2}{|c|}{ Milk ( lit / h ) } & \multirow{2}{*}{$\begin{array}{c}\begin{array}{c}\text { Percent } \\
\text { of } \\
\text { damaged } \\
\text { pack. \% }\end{array} \\
\end{array}$} & \multicolumn{2}{|c|}{$\begin{array}{l}\text { Quantity of packs } \\
\text { ( pack. / h ) }\end{array}$} & \multirow{2}{*}{$\begin{array}{l}\text { Machind } \\
\text { rate } \\
\text { (pack./h) }\end{array}$} \\
\hline & $\begin{array}{l}\text { Quantity of } \\
\text { losses milk }\end{array}$ & $\begin{array}{l}\text { Quantity of } \\
\text { packed milk }\end{array}$ & & $\begin{array}{l}\text { Damaged } \\
\text { pack. }\end{array}$ & $\begin{array}{c}\text { Product } \\
\text { pack. }\end{array}$ & \\
\hline 3.90 & 47.58 & 1220 & 1.30 & 80 & 6100 & 6180 \\
\hline 1.36 & 17.68 & 1300.20 & .60 & 39 & 6501 & 6540 \\
\hline 2.96 & 39.42 & 1331. 80 & .91 & 61 & 6659 & 6720 \\
\hline 1.00 & 13. 78 & 1378. 20 & 1.00 & 69 & 6891 & 6960 \\
\hline 3. 38 & 47.93 & 1418 & .70 & 50 & 7090 & 7140 \\
\hline 4. 22 & 61.23 & 1450. 80 & .90 & 66 & 7254 & 7320 \\
\hline
\end{tabular}

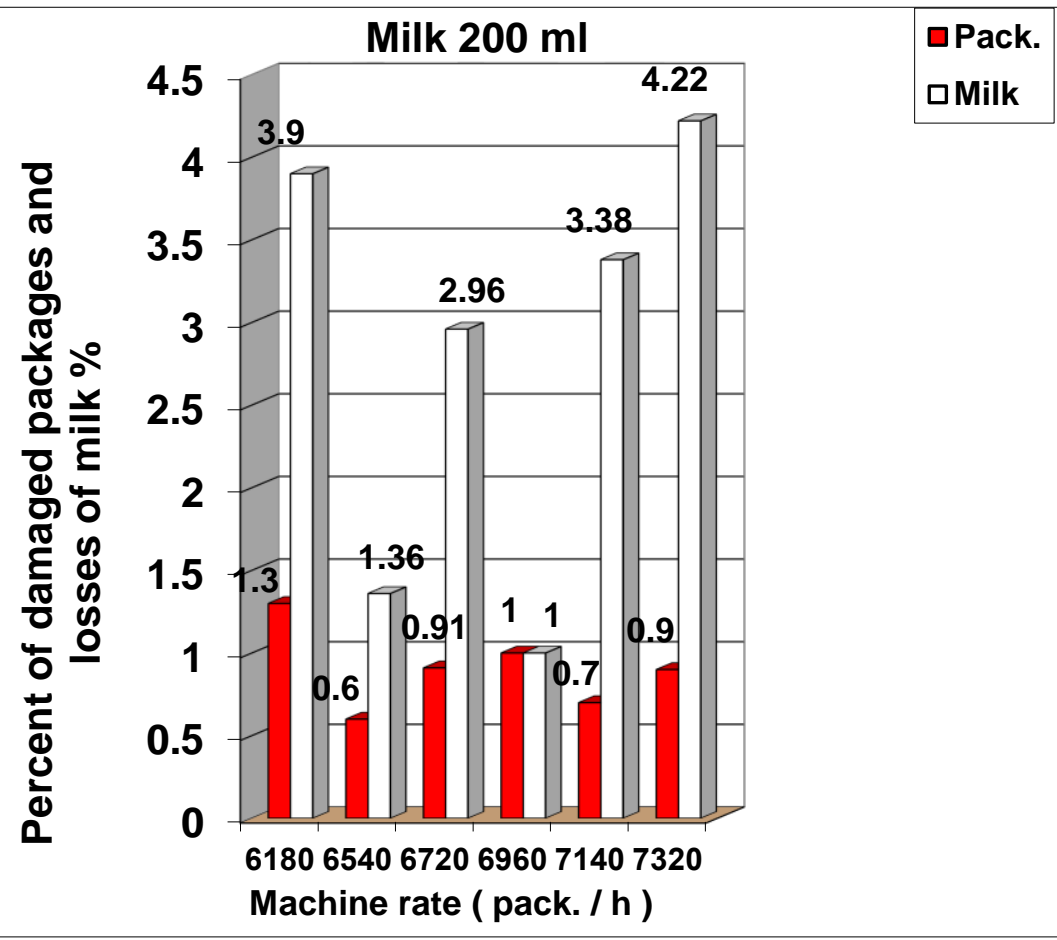

FIG. (4): Comparing between different rate of (Tp. $200 \mathrm{ml})$, damaged milk packages and losses of milk in plant. 
Table (2): Comparison between different rats for milk mix fruit 200 ml produce by tetra pack machine and damaged packages in plant.

\begin{tabular}{|c|c|c|c|c|c|c|}
\hline \multirow{2}{*}{$\begin{array}{l}\text { Percent } \\
\text { of losses } \\
\text { milk \% }\end{array}$} & \multicolumn{2}{|c|}{ Milk ( lit / h ) } & \multirow{2}{*}{$\begin{array}{c}\begin{array}{c}\text { Percent } \\
\text { of } \\
\text { damaged } \\
\text { pack. \% }\end{array} \\
\end{array}$} & \multicolumn{2}{|c|}{$\begin{array}{l}\text { Quantity of packs } \\
\text { ( pack. / h ) }\end{array}$} & \multirow{2}{*}{$\begin{array}{l}\text { Milk } \mathrm{m} \\
\mathrm{fr} \\
\text { Maching } \\
\text { rate } \\
\text { (pack./ h) }\end{array}$} \\
\hline & $\begin{array}{l}\text { Quantity of } \\
\text { losses milk }\end{array}$ & $\begin{array}{l}\text { Quantity of } \\
\text { packed milk }\end{array}$ & & $\begin{array}{c}\text { Damaged } \\
\text { pack. }\end{array}$ & $\begin{array}{c}\text { Product } \\
\text { pack. }\end{array}$ & \\
\hline 2.10 & 25.87 & 1231.80 & 1.30 & 81 & 6159 & 6240 \\
\hline 1.86 & 24.16 & 1298.80 & .70 & 46 & 6494 & 6540 \\
\hline 1.94 & 25.61 & 1320 & .90 & 60 & 6600 & 6660 \\
\hline 1.61 & 21.84 & 1356.60 & 1.70 & 117 & 6783 & 6900 \\
\hline 2.26 & 31.48 & 1392.80 & .80 & 56 & 6964 & 7020 \\
\hline 2.10 & 25.87 & 1231.80 & 1.30 & 81 & 6159 & 6240 \\
\hline
\end{tabular}

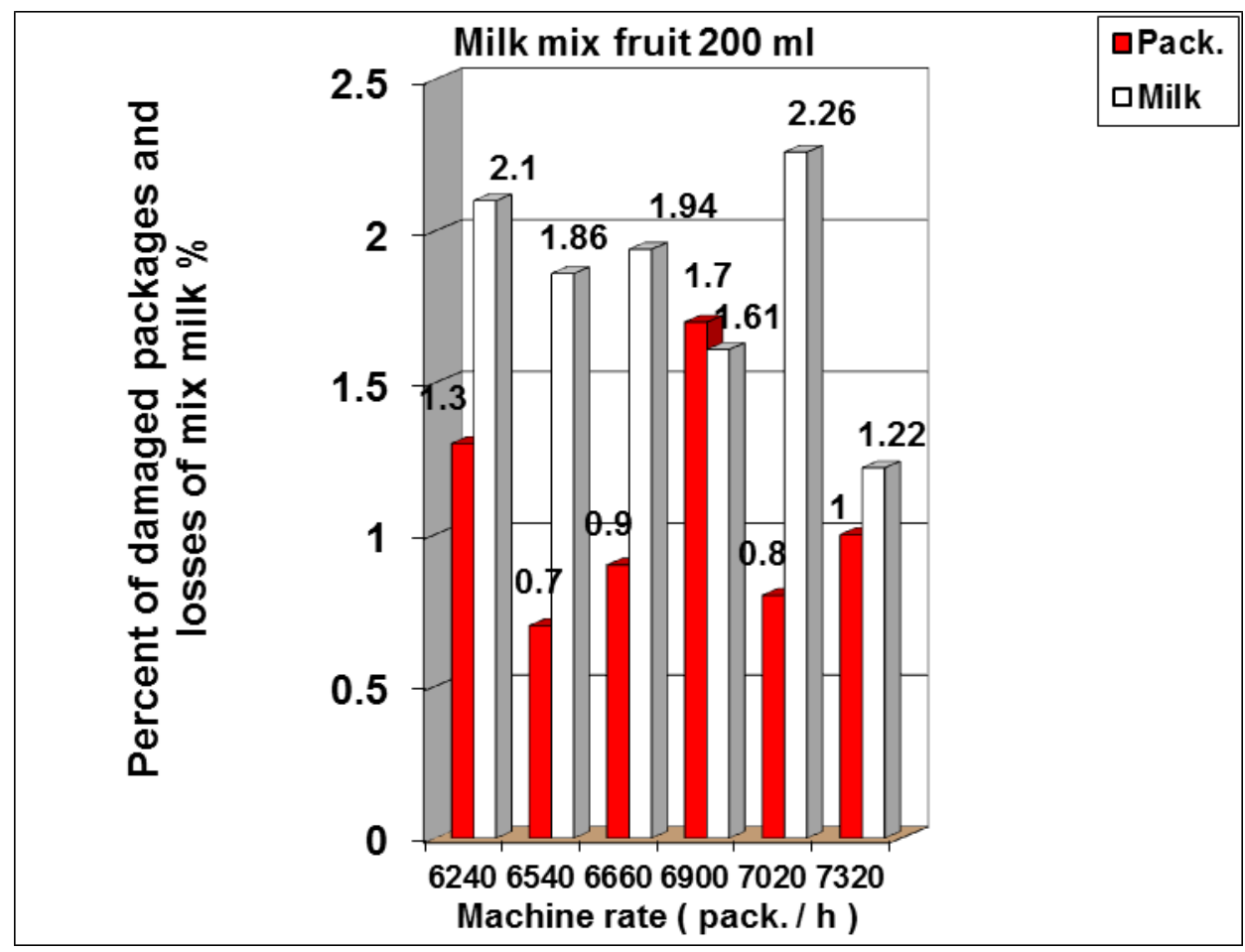

FIG.(5): Comparing between different rate of ( $\mathrm{Tp} .200 \mathrm{ml}$ ), damaged milk packages and losses milk mix fruit in plant. 
Table (3): Comparison between different rats for milk $500 \mathrm{ml}$ produce by tetra pack machine and damaged packages in plant .

\begin{tabular}{|c|c|c|c|c|c|c|}
\hline \multirow{2}{*}{$\begin{array}{l}\text { Percent } \\
\text { of losses } \\
\text { milk \% }\end{array}$} & \multicolumn{2}{|c|}{ Milk ( lit / h ) } & \multirow{2}{*}{$\begin{array}{c}\begin{array}{c}\text { Percent } \\
\text { of } \\
\text { damaged } \\
\text { pack. \% }\end{array} \\
\text {. }\end{array}$} & \multicolumn{2}{|c|}{$\begin{array}{l}\text { Quantity of packs } \\
(\text { pack. / h ) }\end{array}$} & \multirow{2}{*}{$\begin{array}{l}\text { Machino } \\
\text { rate } \\
\text { (pack./h) }\end{array}$} \\
\hline & $\begin{array}{l}\text { Quantity of } \\
\text { losses milk }\end{array}$ & $\begin{array}{l}\text { Quantity of } \\
\text { packed milk }\end{array}$ & & $\begin{array}{c}\text { Damaged } \\
\text { pack. }\end{array}$ & $\begin{array}{c}\text { Product } \\
\text { pack. }\end{array}$ & \\
\hline 3.06 & 61 & 1993. 50 & .82 & 33 & 3987 & 4020 \\
\hline 2.30 & 47.86 & 2081 & .91 & 38 & 4162 & 4200 \\
\hline 3.22 & 71.73 & 2227.50 & 1.00 & 45 & 4455 & 4500 \\
\hline 1.25 & 30.01 & 2401 & 1.20 & 58 & 4802 & 4860 \\
\hline 1.55 & 39.09 & 2522 & 1.10 & 56 & 5044 & 5100 \\
\hline 2.36 & 60.52 & 2564.50 & .60 & 31 & 5129 & 5160 \\
\hline
\end{tabular}

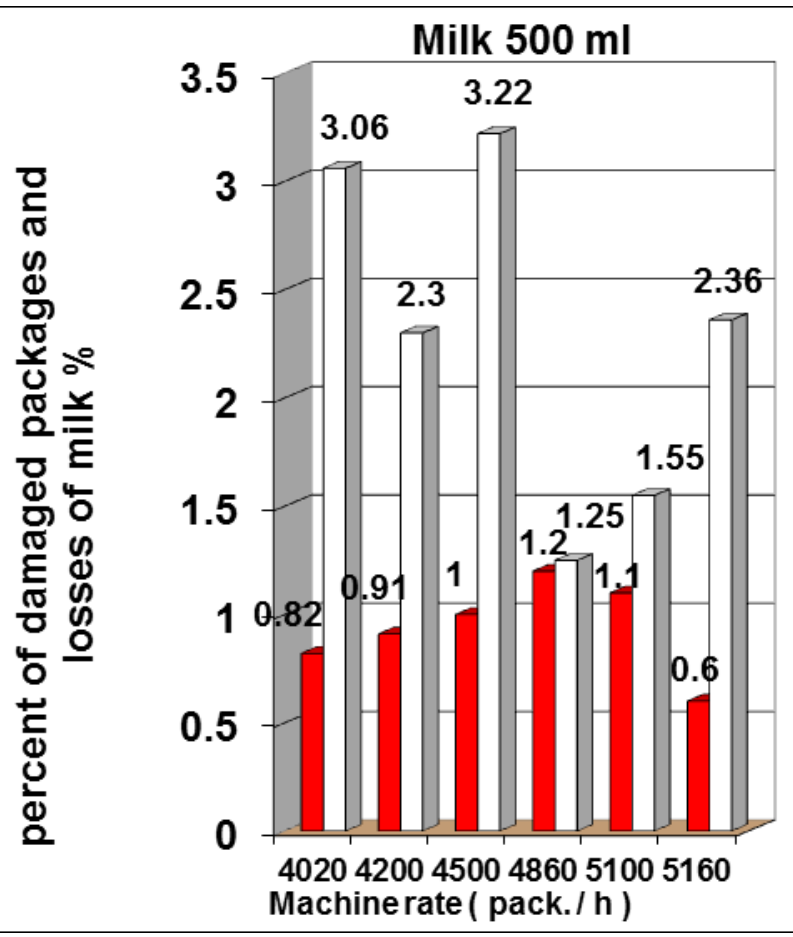

FIG.(6): Compring between different rate of ( $\mathrm{Tp.500} \mathrm{ml}$ ), damaged milk packages and losses milk in plant. 
Table (4): Comparison between different rats for milk $1000 \mathrm{ml}$ produce by tetra pack machine and damaged packages in plant .

\begin{tabular}{|c|c|c|c|c|c|c|}
\hline \multirow{2}{*}{$\begin{array}{l}\text { Percent } \\
\text { of losses } \\
\text { milk \% }\end{array}$} & \multicolumn{2}{|c|}{ Milk ( lit / h ) } & \multirow{2}{*}{$\begin{array}{c}\text { Percent } \\
\text { of } \\
\text { damaged } \\
\text { pack. \% }\end{array}$} & \multicolumn{2}{|c|}{$\begin{array}{l}\text { Quantity of packs } \\
\text { ( pack. / h ) }\end{array}$} & \multirow{2}{*}{$\begin{array}{l}\text { Machind } \\
\text { rate } \\
\text { (pack./ h) }\end{array}$} \\
\hline & $\begin{array}{l}\text { Quantity of } \\
\text { losses milk }\end{array}$ & $\begin{array}{l}\text { Quantity of } \\
\text { packed milk }\end{array}$ & & $\begin{array}{c}\text { Damaged } \\
\text { pack. }\end{array}$ & $\begin{array}{c}\text { Product } \\
\text { pack. }\end{array}$ & \\
\hline 1.13 & 62.30 & 5513 & 1. 20 & 67 & 5513 & 5580 \\
\hline .92 & 51.58 & 5606 & .60 & 34 & 5606 & 5640 \\
\hline 1.08 & 61.22 & 5668 & 1.60 & 92 & 5668 & 5760 \\
\hline 1. 47 & 91.41 & 6218 & 1.30 & 82 & 6218 & 6300 \\
\hline 1. 87 & 119. 57 & 6394 & .41 & 26 & 6394 & 6420 \\
\hline 2.98 & 205.62 & 6900 & .90 & 62 & 6838 & 6900 \\
\hline
\end{tabular}

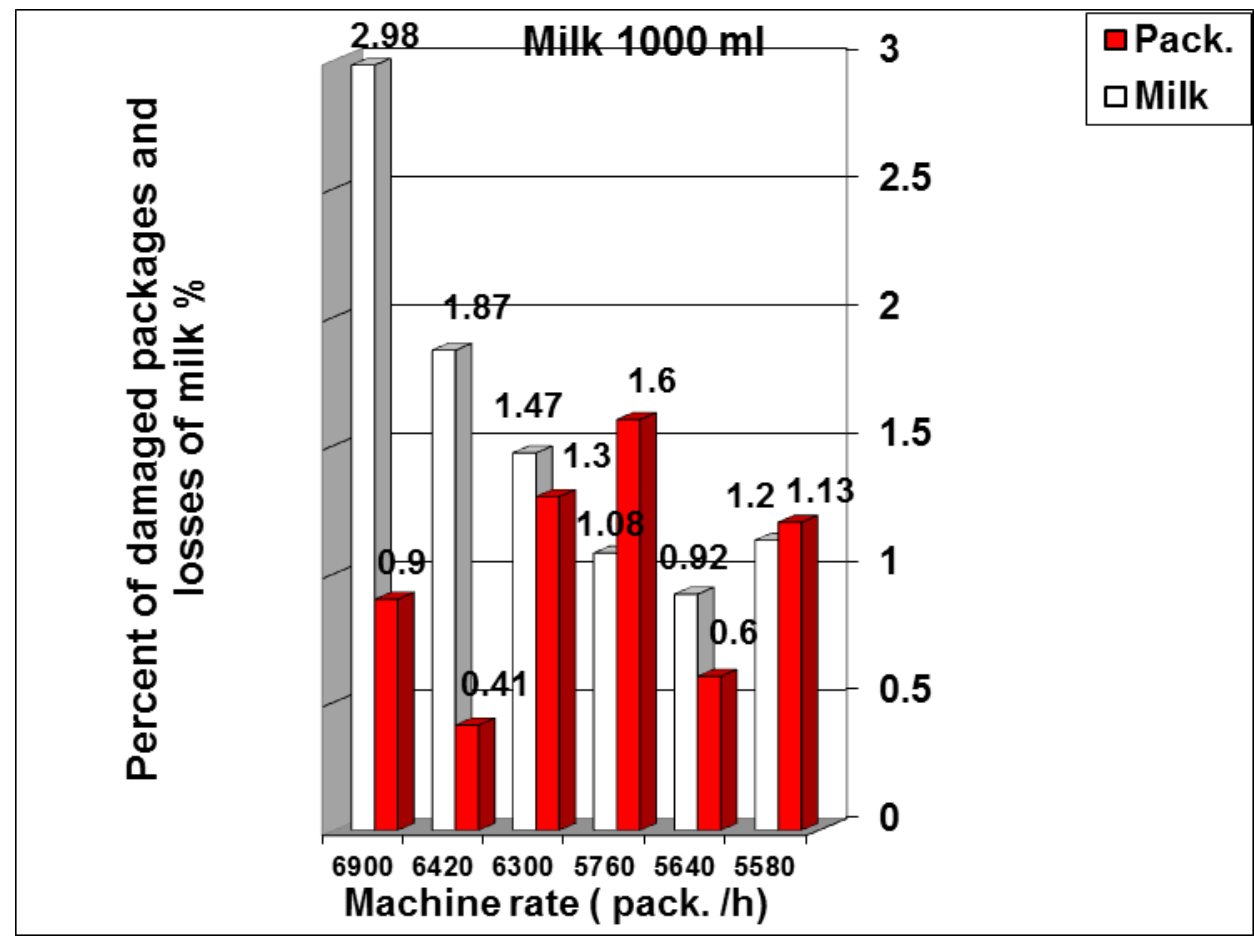

FIG.(7):Comparing between different rat of( Tp.1000 ml ), damaged milk packages and losses milk in plant. 


\section{5- Tetra brick aseptic packaging milk mix fruit $1000 \mathrm{ml}$ in plant :}

Comparing between the different rate for milk mix fruit $1000 \mathrm{ml}$ produce by tetra brick aseptic Packaging machine and damaged packages in addition to quantity of losses milk using six speed were 5640, 5760, 6240, 6300, 6360 and 6960 packages/h with a percentage of damaged packages $/$ hr were $1.81 \%, 0.70 \%, 1.70 \%, 1 \%, 1.80 \%$, and $3.10 \%$ while the losses of mix milk with a percentage of lit/hr were $1.73 \%, 1.93 \%, 1.17 \%$, $2.12 \%, 3.63 \%$, and $3.20 \%$ respectively presented in Tabel (5) and fig.(8). The data can be indicated that the highest value of damaged packages was accompanied with a speed 6960 packages/h, while the lowest one with a speed 5760 packages/h.

\section{6- Tetra brick aseptic packaging vita cheese $250 \mathrm{gm}$ in plant :}

Comparing between the different rate for vita cheese 250 gm produce by tetra brick aseptic packaging machine and damaged packages using six speeds were 4620, 4800, 4920, 5100, 5160 and 5220 packages/h with a percentage of damaged packages were $1.72 \%, 0.29 \%, 0,87 \%, 0.82 \%$, $0.23 \%$, and $1 \%$ respectively are presented in Tabel (6) and Fig.(9). The data can be indicated that the highest value of damaged packages was accompanied with a speed 4620 packages/h, while the lowest one with a speed 5160 packages $/ \mathrm{h}$.

\section{7- Tetra brick aseptic packaging vita cheese $\mathbf{5 0 0} \mathbf{~ g m}$ in plant :}

Comparing between the different rate for vita cheese $500 \mathrm{gm}$ produce by tetra brick aseptic packaging machine and damaged packages using six speeds were 4140, 4260, 4740, 4800, 5040 and 5760 packages/h with a percentage of damaged packages were $0.58 \%, 0.14 \%, 0,55 \%, 0.21 \%, 0.10 \%$, and $0.30 \%$ respectively are presented in Tabel (7) and Fig.(10). The data can be indicated that the highest value of damaged packages was accompanied with a speed 4140 packages/h, while the lowest one with a speed 5040 packages/h. 
Table (5): Comparison between different rats for milk mix fruit 1000 ml produce by tetra pack machine and damaged packages in plant.

\begin{tabular}{|c|c|c|c|c|c|c|}
\hline \multirow{2}{*}{$\begin{array}{l}\text { Percent } \\
\text { of losses } \\
\text { milk \% }\end{array}$} & \multicolumn{2}{|c|}{ Milk ( lit / h ) } & \multirow{2}{*}{ 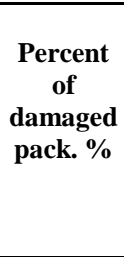 } & \multicolumn{2}{|c|}{$\begin{array}{l}\text { Quantity of packs } \\
\text { ( pack. / h ) }\end{array}$} & \\
\hline & $\begin{array}{l}\text { Quantity of } \\
\text { losses milk }\end{array}$ & $\begin{array}{l}\text { Quantity of } \\
\text { packed milk }\end{array}$ & & $\begin{array}{c}\text { Damaged } \\
\text { pack. }\end{array}$ & $\begin{array}{l}\text { Product } \\
\text { pack. }\end{array}$ & $\begin{array}{l}\text { Machine } \\
\text { rate } \\
\text { (pack./ hr) }\end{array}$ \\
\hline 1.73 & 95.81 & 5538 & 1.81 & 102 & 5538 & 5640 \\
\hline 1.93 & 110.40 & 5720 & .70 & 40 & 5720 & 5760 \\
\hline 1.17 & 71. 77 & 6134 & 1.70 & 106 & 6134 & 6240 \\
\hline 2.12 & 132.23 & 6237 & 1.00 & 63 & 6237 & 6300 \\
\hline 3.63 & 226.73 & 6246 & 1.80 & 114 & 6246 & 6360 \\
\hline 3. 20 & 215.81 & 6744 & 3.10 & 216 & 6744 & 6960 \\
\hline
\end{tabular}

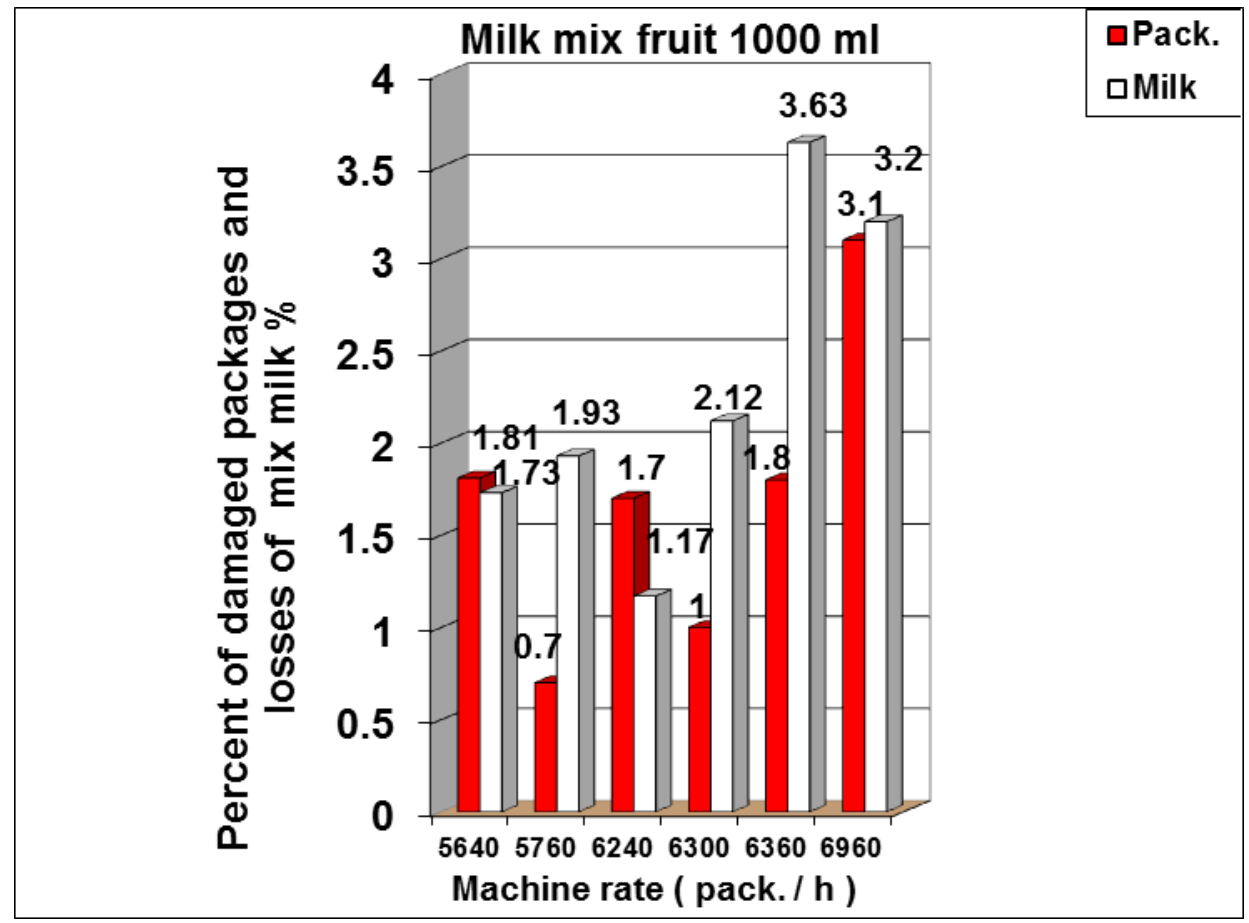

FIG. (8) : Comparing between different rat of ( Tp.1000 ml ), damaged milk packages and losses milk in plant. 
Table (6): Comparison between different rats for vita cheese $250 \mathrm{gm}$ produce by tetra pack machine and damaged packages in plant.

\begin{tabular}{|c|c|c|c|}
\hline $\begin{array}{c}\text { Percent of } \\
\text { damaged } \\
\text { pack \% }\end{array}$ & \multicolumn{2}{|c|}{$\begin{array}{c}\text { Quantity of packs } \\
\text { ( pack. / h ) }\end{array}$} & \multirow{2}{*|}{$\begin{array}{c}\text { Vita 250 gm } \\
\text { rachine } \\
\text { rate } \\
\text { (pack./ h) }\end{array}$} \\
\hline \hline Damaged pack \% & Damaged pack & Product pack & 4620 \\
\hline \hline 1.72 & 79 & 4541 & 4800 \\
\hline .29 & 14 & 4786 & 4920 \\
\hline .87 & 43 & 4877 & 5100 \\
\hline .82 & 42 & 5058 & 5160 \\
\hline .23 & 12 & 5148 & 5220 \\
\hline 1.00 & 52 & 5168 & 5 \\
\hline
\end{tabular}

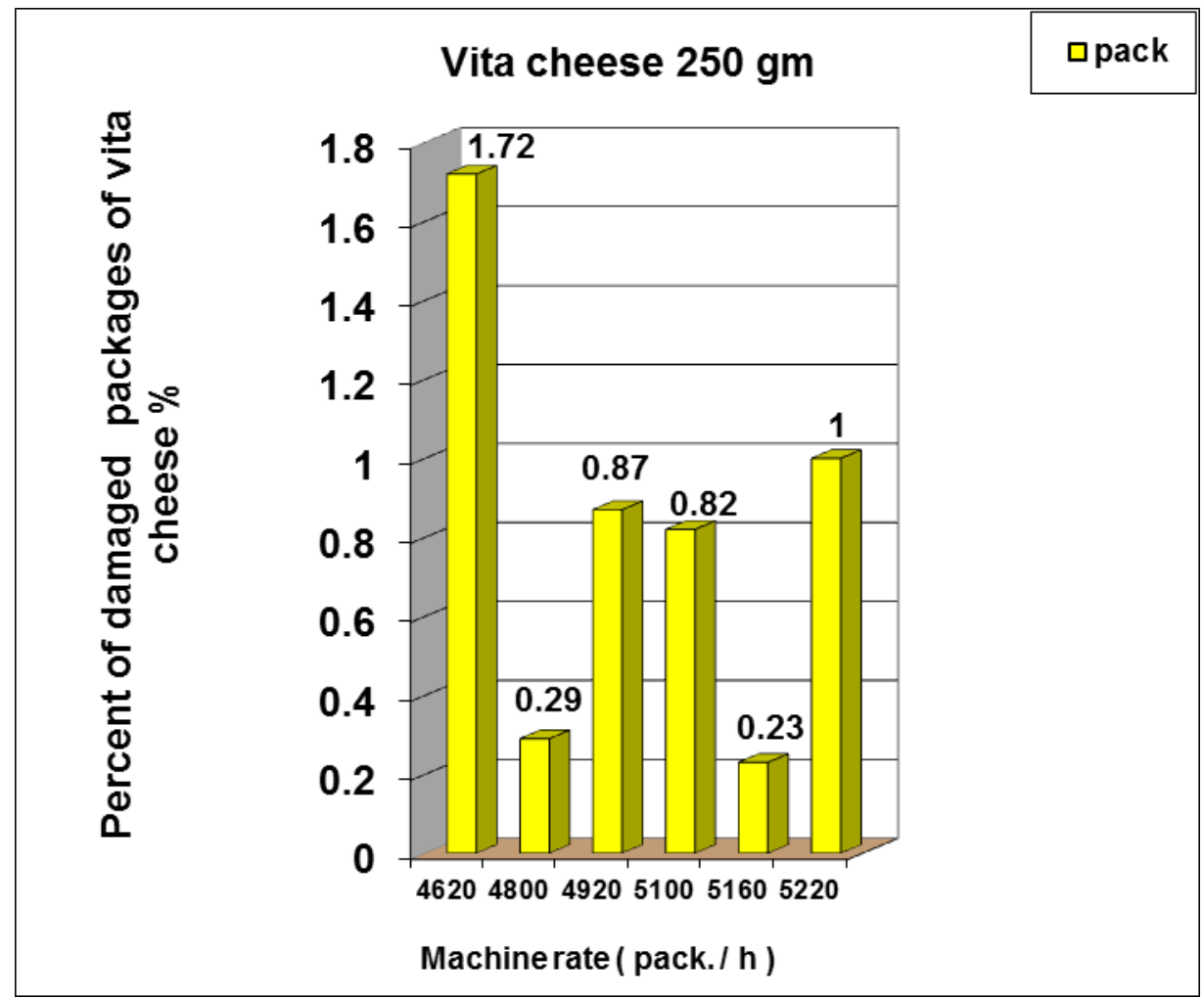

FIG.(9) : Comparing between different rat of ( Tp. $250 \mathrm{gm}$ ), and damaged vita cheese packages in plant. 
Table (7): Comparison between different rats for vita cheese 500 gm produce by tetra pack machine and damaged packages in plant.

\begin{tabular}{|c|c|c|c|}
\hline $\begin{array}{c}\text { Percent of } \\
\text { damaged } \\
\text { pack. \% }\end{array}$ & \multicolumn{2}{|c|}{$\begin{array}{l}\text { Quantity of packs } \\
\text { ( pack. / h ) }\end{array}$} & \\
\hline Damaged pack. \% & Damaged pack. & Product pack. & $\begin{array}{l}\text { rate } \\
\text { (pack./ h) }\end{array}$ \\
\hline .58 & 24 & 41116 & 4140 \\
\hline .14 & 6 & 4254 & 4260 \\
\hline .55 & 26 & 4714 & 4740 \\
\hline .21 & 10 & 4790 & 4800 \\
\hline .10 & 5 & 5035 & 5040 \\
\hline .30 & 17 & 5743 & 5760 \\
\hline
\end{tabular}

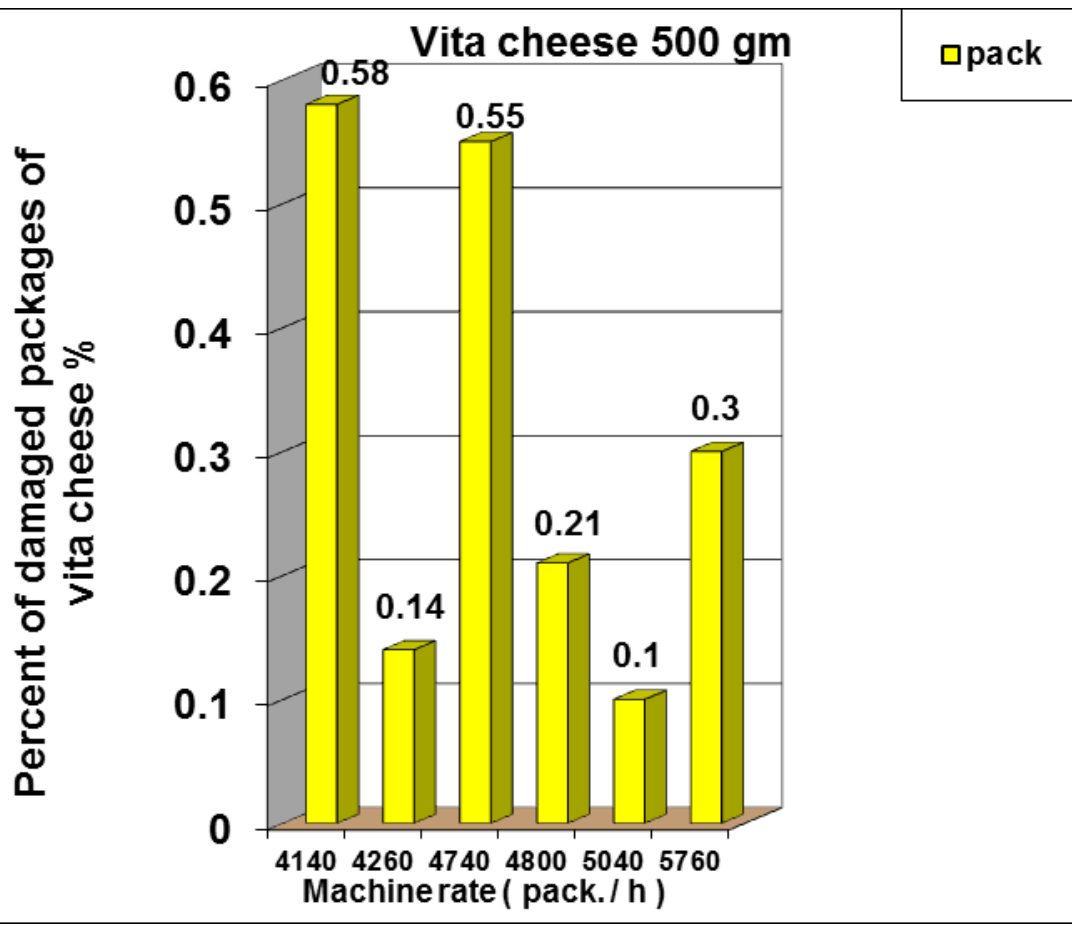

FIG.(10) Comparing between different rat of ( Tp. $500 \mathrm{gm}$ ), and damaged vita chees packages in plant. 


\section{CONCLUSION}

1- The percentage of damage packages $/ \mathrm{h}$ were $(1.30 \%, 0.60 \%, 0.91 \%$, $1 \%, 0.70 \%$, and $0.90 \%$ ) while the quantity losses of milk with a percentage of lit/h were $(3.90 \%, 1.36 \%, 2.96 \%, 1 \%, 3.38 \%$, and $4.22 \%)$ for TP milk $200 \mathrm{ml}$ in plant at machine rate $(6180,6540,6720,6960$, 7140 and 7320) packages/h respectively.

2- The percentage of damage packages/h were $(1.30 \%, 0.70 \%, 0.90 \%$, $1.70 \%, 0.80 \%$, and $1 \%$ ) while the quantity losses of milk with a percentage of lit/h were $(2.10 \%, 1.86 \%, 1.94 \%, 1.61 \%, 2.26 \%$, and $1.22 \%$ ) for TP milk mix fruit $200 \mathrm{ml}$ in plant at machine rate 6240, $6540,6660,6900,7020$ and 7320 packages/h respectively.

3 - The percentage of damage packages $\mathrm{h}$ were $(0.82 \%, 0.91 \%, 1 \%$, $1.20 \%, 1.10 \%$, and $0.60 \%$ ) while the quantity losses of milk with a percentage of lit/h were $(3.06 \%, 2.30 \%, 3.22 \%, 1.25 \%, 1.55 \%$, and $2.36 \%$ ) for TP milk $500 \mathrm{ml}$ in plant at machine rate 4020, 4200, 4500, 4860, 5100 and 5160 packages/h respectively.

4- The percentage of damage packages/h were $(1.20 \%, 0.60 \%, 1.60 \%$, $1.30 \%, 0.41 \%$, and $0.90 \%$ ) while the quantity losses of milk with a percentage of lit/h were $(1.13 \%, 0.92 \%, 1.08 \%, 1.47 \%, 1.87 \%$, and $2.98 \%$ ) for TP milk $1000 \mathrm{ml}$ in plant at machine rate 5580, 5640, 5760, 6300, 6420 and 6900 packages/h respectively.

5- The percentage of damage packages/h were $(1.81 \%, 0.70 \%, 1.70 \%$, $1 \%, 1.80 \%$, and $3.10 \%$ ) while the quantity losses of milk with a percentage of lit/h were $(1.73 \%, 1.93 \%, 1.17 \%, 2.12 \%, 3.63 \%$, and $3.20 \%$ ) for TP milk mix fruit $1000 \mathrm{ml}$ in plant at machine rate 5640, 5760, 6240, 6300, 6360 and 6960 packages/h respectively.

6- The results and obtained data cleared that the suitable machine rate using six different packaging rates for each volum \& product for milk 200 ml, mix milk $200 \mathrm{ml}$, milk $500 \mathrm{ml}$ milk $1000 \mathrm{ml}$ and mix milk $1000 \mathrm{ml}$ were $(7140,6540,5160,6420 \& 5760) \mathrm{pack} / \mathrm{h}$ in the plant respectively.

6- The percentage of damage packages/h were $(1.72 \%, 0.29 \%, 0,87 \%$, $0.82 \%, 0.23 \%$, and $1 \%$ ) for TP vita cheese $250 \mathrm{gm}$ in plant at machine rate $(4620,4800,4920,5100,5160$ and 5220) packages/h respectively. 
7- The percentage of damage packages/h were $(0.58 \%, 0.14 \%, 0,55 \%$, $0.21 \%, 0.10 \%$, and $0.30 \%$ ) for TP vita cheese $500 \mathrm{gm}$ in plant at machine rate $4140,4260,4740,4800,5040$ and 5760 packages/h respectively.

\section{REFERENCES}

Alberto R.and Giulia S.(2013).[ Industrial Engineering and Management ] "Operations Management", Chapter 8 The Important Role of Packaging in Operations Management", book edited by Massimiliano M. Schiraldi, ISBN 978-953-51-1013-2, Published: March 13, 2013 under CC BY 3.0 license. (C) The Author(s).

Chauhan A.K., Kalra K.K., Raj Vir Singh and Raina B.B. (2006). A Study on the Economics of Milk Processing in a Dairy Plant in Haryana Agricultural Economics Research Review Vol. 19 JulyDecember 2006 pp 399-406.

Choudhary, A.K. (1989). Research Needs For Developing Dairy Industry. Indian, Journal of Dairy Man; 41(1): P.P.17-20.

Hassanain, T.M.; Mashhour, A.F.; Laban and Kassem (2005). Economic of Whithe and Dry Cheese Production in Egypt. Zagazig Jourrnal of Agricultural Research; vol(32), May no.(3) : P.P.1031-1058.

E.E.A.A.I.M.(2015)http://industry.eeaa.gov.eg/publications/arDairy\%25 20IM. pdfEgyptian Environmental Affairs Agency Inspection Manual For the manufacture of dairy products (2015)

Dairy-technology. (2014) http://dairy-technology.blogspot.com/2014/01/ milk-losses-in-dairy-plants.html

Wikipedia (2014) http://en.wikipedia.org/wiki/Aseptic_processing

Kishor Gedam Mr. , (2007) The Study on UHT Processing of Milk: A Versatile Option for Rural Sector World Journal of Dairy \& Food Sciences 2 (2): 49-53, 2007 ISSN 1817-308X

Sri-Hari-Rao,K. (1990). Reduction of Losses in Dairy Industary. Indian Dairy Man ; 42 (4): P.P. 190- 197. 


\section{الملخص العربي \\ فو اقد تعبئة اللبن والجبنة الفيتا فى مصنع البان \\ د. وليد محمد حنفى شحاتهة}

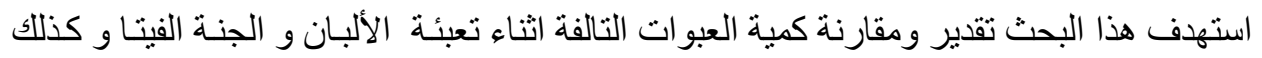

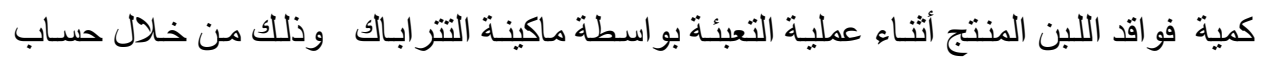

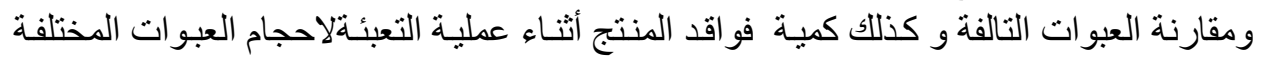

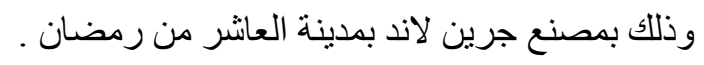
و قد تبين من النتائج المتحصل عليها كل مما يأتي :

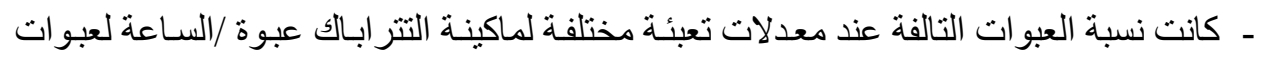

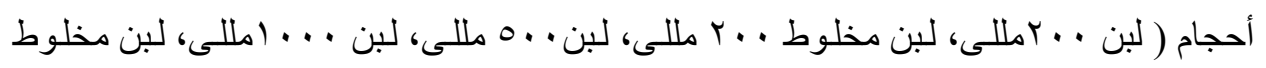

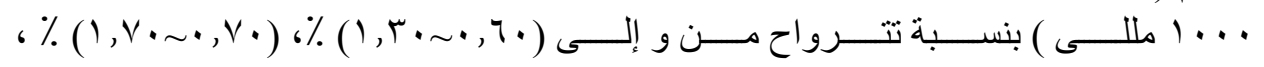

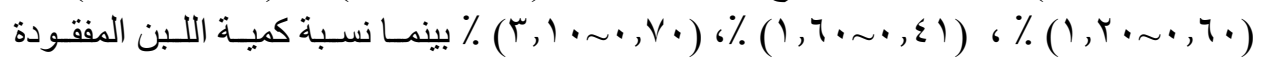
تترواح من و إلى (r,

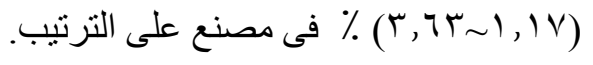

ـ كانت نسبة العبوات التالفة عند معدلات تعبئة مختلفة لماكينة التتر اباك للجبن الفيتا لعبوات .

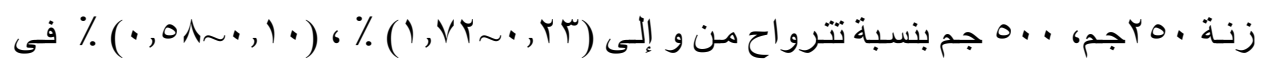
مصنع على الترتيب.

المعدل الأمثل و الفضـل حسب مـا توصلت البـه نتائج البحث للتعبئة بواسطة ماكينة التتر ابـاك وذللك اثناء تعبئة الألبان وكذلك الجبنة الفيتا بالمصنع كانت كما يلى :

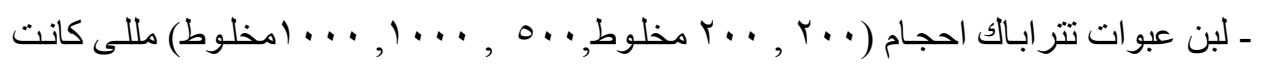

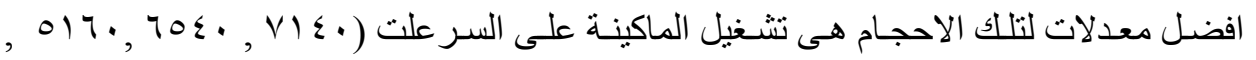

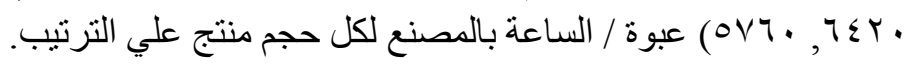

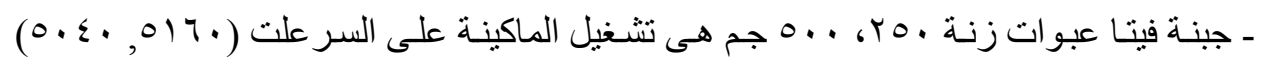

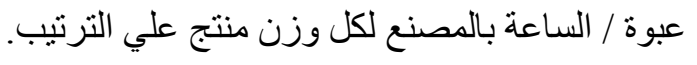

*مدرس بقسم الهندسة الزراعية ـ كلية الزراعة والموارد المائية ـ جامعة اسوان. 